\title{
PERANAN PEMERINTAH DALAM PEMBERDAYAAN USAHATANI HOLTIKULTURA DI KABUPATEN BIAK NUMFOR
}

\author{
David J. J. D. Sabarofek \\ Lyndon R. J. Pangemanan \\ Mex L. Sondakh
}

\begin{abstract}
ABSRACT
The purpose of this study is to determine: (1) how the role of the Department of Agriculture in Empowering Horticulture Farmers in Biak Numfor District, (2) constraints faced by farmers in horticulture farming in Dofyo Wafor Village, North Biak District, Biak Numfor District, Papua Province. This research was conducted for 3 months starting from March until May 2017. This research uses qualitative research approach. Primary data were collected by interviews and field observations. Respondents were selected by purposive sampling method as many as 30 respondents selected from 3 farmer groups in the village of Dofyo Wafor. Secondary data collection is obtained from the literature derived from related agencies such as: Animal Husbandry and Food Crop Farming Biak Numfor District. Central Bureau of Statistics of Biak Numfor Regency. Technical Service Unit of Agricultural Extension Institute of Biak Utara District and Dofyo Wafor Village Office. Data analysis used is qualitative analysis. The research found that (1) Government in empowering horticulture farm in Biak Numfor Regency. Particularly in Dofyo Wafor Village, through the Livestock and Food Crops Office of Biak Numfor District has empowered farmers, empowerment carried out in the form of counseling, seed breeder supervisors, providing superior seed support, irrigation irrigation facilities, technological advancement, assistance in land management, and assistance in farmer institutions; (2) The existing obstacles are pest and disease attack on agricultural crops, limited knowledge, skills and capital of farmers, and also the bargaining position of agricultural products that are still low.
\end{abstract}

Keywords: government role, horticulture farming empowernment, Biak Numfor District

\begin{abstract}
ABSTRAK
Tujuan penelitian ini adalah untuk mengetahui: (1) bagaimana Peranan Dinas Pertanian Dalam Pemberdayaan Petani Hortikultura di Kabupaten Biak Numfor. (2) kendala yang di hadapi oleh petani dalam usahatani hortikultura di Desa Dofyo Wafor, Kecamatan Biak Utara, Kabupaten Biak Numfor, Provinsi Papua.. Penelitian ini dilaksanakan selama 3 bulan dari bulan Maret sampai bulan Mei 2017. Penelitian ini menggunakan pendekatan penelitian kualitatif. Data primer dikumpulkan dengan wawancara dan pengamatan lapangan. Pemilihan responden ditentukan secara sengaja (purposive sampling) jumlah responden yang dijadikan sampel sebanyak 30 responden dipilih dari 3 kelompok tani yang ada di Desa Dofyo Wafor. Pengumpulan data sekunder diperoleh dari literatur yang berasal dari instansi-instansi yang terkait antara lain: Dinas Peternakan Dan Pertanian Tanaman Pangan Kabupaten Biak Numfor. Badan Pusat Statistik Kabupaten Biak Numfor.Unit Pelayanan Teknis Balai Pelaksana Penyuluh Pertanian Kecamatan Biak utara.dan Kantor Desa Dofyo Wafor. Analisa data yang digunakan adalah analisa kualitatif. Berdasarkan penelitian yang dilakukan maka diperoleh kesimpulan bahwa (1) Pemerintah dalam pemberdayaan usahatani hortikultura di Kabupaten Biak Numfor. Khususnya di Desa Dofyo Wafor, melalui Dinas Peternakan dan Pertanian Tanaman Pangan Kabupaten Biak Numfor telah melakukan pemberdayaan kepada petani, pemberdayaan yang dilakukan dalam bentuk penyuluhan, pengawas penangkar benih, pemberikan bantuan bibit unggul, sarana irigasi pengairan, pendorong kemajuan teknologi, pendampingan dalam pengelolaan lahan, dan pendampingan dalam kelembagaan petani. (2) Adapun hambatan yang ada yaitu adanya serangan hama dan penyakit pada tanaman pertanian, terbatasnya pengetahuan, ketrampilan dan permodalan petani, dan juga posisi tawar produk pertanian yang masih rendah.
\end{abstract}

Kata kunci: peranan pemerintah, pemberdayaan usahatani holtikultura, Kabupaten Biak Numfor 


\section{PENDAHULUAN}

\section{Latar Belakang}

Pengembangan hortikultura di Indonesia pada umumnya masih dalam skala perkebunan rakyat yang tumbuh dan dipelihara secara alami dan tradisional, sedangkan jenis komoditas hortikultura yang diusahakan masih terbatas. Hasil pertanian tanaman hortikultura seperti sayur-sayuran dan buah-buahan adalah hasil yang diolah para petani di daerah relatif masih tergolong subsisten, diduga masyarakat masih kurang tertarik dalam berusahatani secara komersil, dimana sebagian dari hasil produksi tanaman hortikultura di konsumsi sendiri. Komoditas hortikultura khususnya sayursayuran dan buah-buahan memegang bagian terpenting dari keseimbangan pangan, sehingga harus tersedia setiap saat dalam jumlah yang cukup, mutu yang baik, aman dikonsumsi, harga yang terjangkau, serta dapat diakses oleh seluruh lapisan masyarakat. Untuk memenuhi kebutuhan dan kesejahteraan masyarakat sebagai tujuan dicapai dalam proses pembangunan daerah yang tak terpisakan oleh program dan kebijakan pembangunan daerah. Mengingat bahwa hakikat dari pelaksanaan otonomi daerah yang paling substansial adalah peningkatan kesejahteraan masyarakat, maka dalam hal ini tugas itu tentu saja berada ditangan Pemerintah Daerah, dimana Dinas Peternakan dan Pertanian Tanaman Kabupaten Biak Numfor yang merupakan bagian dari pemerintah daerah diharapkan dapat menyelenggarakan dan melakukan pembinaan, pelaksanaan dan kerja teknis pada masyarakat petani terutama pada usahatani hortikultura.

Pengembangan dalam sektor pertanian harus mengantisipasi tantangan demokratisasi dan globalisasi untuk dapat menciptakan sistem yang adil. Selain itu harus diarahkan untuk mewujudkan masyarakat sejahtera khususnya petani melalui pembangunan sistem pertanian yang mapan. Sistem tersebut harus berkerakyatan, berkelanjutan dan desentralistik. Berdaya saing, berarti pertanian kita dapat disejajarkan dengan produk pertanian di daerah lain baik jumlah maupun kualitasnya. Berkerakyatan, berarti bahwa setiap usaha pembangunan pertanian harus mengikutsertakan petani supaya semakin berdaya sebagai subyek pembangunan. Berkelanjutan berarti pembangunan pertanian harus memberikan jaminan bagi keberlangsungan sektor pertanian, sedangkan terdesentralisasi mempunyai makna bahwa pengembangan sektor pertanian yang dibuat oleh Dinas Tanaman Pangan dan Holtikultura juga harus berdasarkan aspirasi dan keinginan petani sesuai dengan kebutuhannya. Disini peranan pemerintah khususnya Dinas Peternakan dan Pertanian Tanaman Pangan sangat dibutuhkan, contohnya mengeluarkan kebijakan-kebijakannya dengan tidak memberatkan petani seperti menyelenggarakan kredit modal usaha tani dengan bunga yang sangat rendah, atau dengan mengadakan program pupuk murah yang dapat didistribusikan langsung ke pada petani. Peranan Pemerintah dalam mengembangkan usahatani hortikultura kegiatan utama yang dilakukan adalah pengembangan sarana dan prasarana penunjang serta peningkatan penggunaan bibit unggul dan input teknologi lainnya. Selama ini ketergantungan petani yang besar pada saluran distribusi saprodi dan penangkar bibit kadang memberatkan petani.

Dari segi potensi pertanian, Kabupaten Biak Numfor memiliki potensi yang cukup baik sebagai penghasil produk hortikultura yang cukup menjanjikan. Potensi pertanian di Kabupaten Biak Numfor meliputi tanaman palawija berupa umbi-umbian di Distrik Yendidori, Biak Barat, Swandiwe, Samofa, Andey, Bondifuar dan Numfor, Sendangkan untuk tanaman hortikultura berupa sayursayuran dan buah-buahan terdapat di Distrik Biak Timur, Oridek, Yendidori dan Biak Utara. Jenis sayuran yang terdapat di Kabupaten Biak Numfor, pada dasarnya seluruh komoditas pangan (tanaman pangan dan hortikultura) yang dibutuhkan, baik untuk memenuhi kebutuhan konsumsi penduduk maupun untuk peningkatan pendapatan petani yang perlu ditingkatkan. Luas lahan garapan tanaman pangan dan hortikultura sekitar 3.677 hektar dengan luas panen sekitar 1.706 hektar, Adapun pengembangan tanaman seperti. jagung, umbiumbian, kacang ijo, sayur-sayuran, buahbuahan dan lain-lain. Sektor pertanian bagi Kabupaten Biak Numfor masih mempunyai pengaruh yang besar terhadap perkembangan kontribusi PDRB di daerah dan masih mempunyai peranan yang besar terhadap kehidupan masyarakat mengingat mayoritas 
penduduknya bermata pencaharian sebagai petani. Dari seluruh potensi sumberdaya lahan pertanian yang ada, sangat potensial untuk dimanfaatkan guna peningkatan pendapatan masyarakat dengan sumberdaya alam tersebut, selama ini keberadaan petani berfungsi sebagai produsen sekaligus manajer dalam pengelolaan usaha taninya dengan berbagai kondisi kemampuan pendanaan, pengetahuan dan ketrampilan serta manajemen yang relatif sangat terbatas. Pembangunan pertanian di Kabupaten Biak Numfor ditempuh dengan prioritas program ketahanan pangan dan pengembangan agribisnis, program pengembangan sumberdaya pertanian, dan program pengembangan IPTEK. Seiring perkembangan saat ini dimana peran pemerintah telah berubah dari pelaksanaan menjadi fasilitator, dinamisator, dan koordinator dalam pembangunan, maka partisipasi masyarakat diperlukan untuk mendukung proses perubahan tersebut. Untuk itu masyarakat petani di Desa Dofyo Wafor juga merasa terpanggil untuk berperan aktif berusaha memberdayakan diri tanpa menghilangkan unsur-unsur positif yang telah diberikan oleh pemerintah.

Disini penulis melakukan penelitian di Desa Dofyo Wafor Distrik Biak utara, terutama pada masyarakat petani sehubung dengan Peranan Pemerintah dalam pemberdayaan usahatani hortikultura di Kabupaten Biak Numfor. Masyarakat petani di Desa Dofyo Wafor adalah mayoritas masyarakat transmigrasi dari luar Papua (Kabupaten Biak Numfor) berasal dari Jawa dan Sulawesi selatan yang berdomisili dan sedang berusahatani secara alamia dan tradisional, serta bekerjasama (gotong-royong) dengan masyarakat lokal sebagai petani. Lahan yang disediakan oleh pemerintah untuk masyarakat transmigrasi telah mereka manfaatkan sebagai lahan pertanian untuk menanam berbagai macam jenis tanaman hortikultura. Seperti (cabai, tomat, kubis, bawang daun, kankung, jahe dan jeruk). Cara mereka berusahatani juga masih sederhana mereka mengunakan peralatan seadanya, pemberdayaan yang selama ini di berikan oleh pemerintah melalui pemberdayaan dan penyuluhan kepada mereka sudah di jalankan namun masih terbangkalai tidak berjalan sepenuhnya dengan baik seperti penyediaan saprodi (sarana produksi) pemberian pupuk, peminjaman modal sehingga mereka berusahatani mengunakan modal sendiri. Berbagai permasalahan, seperti kelangkaan pupuk, fluktuasi harga, pemasaran, dan kendala permodalan perlu di atasi. Penelitian ini akan mengkaji peranan pemerintah dalam memberdayakan usahatani hortikultura di Kabupaten Biak Numfor. khususnya di Desa Dofyo Wafor. Melalui tahap perumusan ini, Pemerintah Kabupaten Biak Numfor diharapkan mampu menganalisa keputusan-keputusan kondisional yang ada untuk ditetapkan menjadi sebuah tujuan.

\section{Perumusan Masalah}

Berdasarkan permasalahan yang dihadapi oleh para petani maka masalah pokok yang akan diteliti adalah peranan Dinas Pertanian Dalam Pemberdayaan Petani Hortikultura di Kabupaten Biak Numfor khususnya pada Desa Dofyo Wafor Kecamatan Biak utara.

\section{Tujuan Penelitian}

1. Tujuan penelitian ini adalah untuk mengetahui dan menjelaskan bagaimana Peranan Dinas Pertanian Dalam Pemberdayaan Petani Hortikultura di Kabupaten Biak Numfor.

2. Mengetahui kendala yang di hadapi oleh petani dalam usahatani hortikultura di Desa Dofyo Wafor.

\section{Manfaat Penelitian}

1. Bagi penulis dapat mengetahui lebih jauh tentang peran dan fungsi Dinas Tanaman Pangan dan Holtikultura dalam Pengembangan Sektor Pertanian.

2. Sebagai masukan bagi dinas dalam membuat suatu program dalam pengembangan pertanian.

\section{METODOLOGI PENELITIAN}

\section{Waktu dan Tempat Penelitian}

Penelitian ini dilaksanakan selama 3 bulan yaitu mulai dari bulan Maret sampai bulan Mei 2017, mulai dari persiapan sampai penyusunan laporan penelitian. Tempat penelitian ini dilaksanakan di Desa Dofyo Wafor Distrik Biak Utara Kabupaten Biak Numfor Provinsi Papua.

\section{Perspektif Pendekatan Penelitian}

Penelitian ini di katagorikan sebagai penelitian kualitatif, karena hanya mencari fakta 
dan selanjutnya menjelaskan secara deskriptif tentang fakta yang bersangkutan dan tidak dimaksudkan untuk menguji hipotesis tertentu tetapi menggambarkan apa adanya. Menurut pendapat Kirk dan Miller (Moleong, 2003) dinyatakan bahwa "penelitian kualitatif merupakan tradisi tertentu dari ilmu sosial yang secara fundamental bergantung kepada pengamatan manusia dalam wilayahnya sendiri dan berhubungan dengan orang-orang tersebut dalam bahasa dan istilah yang digunakan".

\section{Metode Pengambilan Sampel}

1. Data tentang peranan pemerintah dilakukan melalui wawancara dengan pemerintah dinas pertanian melalui kepala dinas dan kepala bidang untuk melihat bagaimana peranan pemerintah dalam pemberdayaan usahatani hortikultura yang telah dilaksanakan mengunakan pertanyaan yang sudah di siapkan pada kuisoner responden dan wawancara secara mendalam.

2. Data petani diperoleh melalui pengamatan dilapangan dan wawancara dengan petani atau pengurus kelompok. dimana dalam menentukan responden dilakukan secara sengaja (purposive sampling) jumlah responden yang dijadikan sampel sebanyak 30 responden dipilih dari 3 kelompok tani yang ada di Desa Dofyo Wafor.

\section{Metode Pengumpulan Data}

Data yang diperlukan dalam penelitian ini meliputi dua unsur yaitu, data primer dan data sekunder: Data primer diperoleh dari pengamatan dan wawancara langsung dengan respoden berdasarkan daftar pertanyaan (kuisioner) dengan data yang diperlukan adalah Pengumpulan data primer diperoleh dari dinas terkait dan petani responden melalui wawancara dengan menggunakan kuesioner dan pengamatan langsung dilapangan.

1. Data dari dinas pertanian melakukan wawancara secara umum dengan kepada dinas dan kepala bidang hotikultura mengenahi perkembangan usahatani hortikultura, Jenisjenis bantuan yang diberikan dalam bentuk peralatan, bahan, modal, pelatihan maupun pelayanan penyuluhan.

2. Data dari individu petani Identitas petani meliputi: umur, pendidikan terakhir, luas lahan, kepemilikan lahan, jenis usahatani yang diusahakan, jumlah tanggungan keluarga, jenis usahatani yang diusahakan, dan jenis bantuan yang diterima.

Pengumpulan data sekunder diperoleh dari literatur yang berasal dari instansi-instansi yang terkait guna untuk memberikan. Gambaran latar belakang penelitian ini mempunyai fungsi sebagai rekomendasi lebih lanjut informasi tentang monografi daerah penelitian juga memberikan indikasi tentang karakteristik sosial ekonomi, pendidikan, dan lain-lain yang berhubungan dengan penelitian ini antara lain:

1. Dinas Peternakan Dan Pertanian Tanaman Pangan Kabupaten Biak Numfor.

2. Badan Pusat Statistik Kabupaten Biak Numfor.

3. Unit Pelayanan Teknis Balai Pelaksana Penyuluh Pertanian Kecamatan Biak utara.

4. Kantor Desa Dofyo wafor.

\section{Teknik Pengumpulan Data}

a. Teknik Wawancara (Interview)

Interview adalah teknik pengambilan data dengan cara melakukan wawancara atau mengajukan pertanyaan langsung pada responden, guna mendapatkan informasi yang diperlukan secara langsung denga responden di tempat penelitian. Adapun tujuan menggunakan teknik pengumpulan data ini adalah untuk memperoleh penjelasan lebih lanjut mengenai data atau fenomena yang ada ditempat penelitian. Adapun responden yang dijadikan data wawancara antara lain:

1. Kepala Dinas Pertanian Tanaman Pangan dan Hortikultura Kabupaten Biak Numfor.

2. Kepala Bidang Tanaman Pangan dan Hortikultura Kabupaten Biak Numfor.

3. 30 Orang petani dari 3 kelompok tani yang ada di Desa Dofyo Wafor.

\section{b. Teknik Dokumentasi}

Data dokumentasi dapat berasal dari koran, majalah, kajian-kajian ilmiah, yang dalam hal ini merupakan kajian-kajian masalah pertanian, kemudian dari makalah-makalah seminar tentang pertanian, dan sebagainya. Adapun dokumen-dokumen yang diperlukan dalam penelitian ini adalah berupa arsip-arsip, catatan monografi, dan catatan-catatan lain yang diperlukan dalam penelitian ini, yang ada di Dinas Peternakan dan Pertanian Tanaman Pangan Kabupaten Biak Numfor, dan juga pada Pemerintahan Desa Dofyo Wafor maupun yang ada di perpustakaan yang berkaitan dengan penelitian ini. 


\section{Konsepsi Pengukuran Variabel}

1. Identifikasi Perkembangan dan Kegiatan Dinas Pertanian Kabupaten yang berhubungan dengan pemberdayaan petani hortikultura.

2. Perkembangan kontribusi PDRB sektor pertanian dan sub sektor tanaman hortikultura terhadap total PDRB Kabupaten Biak Numfor.

3. Perkembangan jumlah petani hortikultura di Kabupaten Biak Numfor.

4. Perkembangan Luas lahan dan produksi komuditi hortikultura.

5. Karakteristik Responden masyarakat petani:

a. Umur Petani

b. Tingkat Pendidikan Terakhir

c. Luas Lahan Yang diusahakan (Ha)

d. Kepemilikan Lahan

e. Jenis Usatani yang diusahakan

f. jenis Bantuan yang diterima

\section{Analisis Data}

Menurut Natsir (2003). analisa data merupakan bagian penting dalam metode ilmiah karena dengan dianalisa, data tersebut dapat diberi arti dan makna yang berguna dalam memecahkan masalah penelitian yang sesuai dengan keadaan yang sebenarnya dilapangan. Berdasarkan uraian yang telah disampaikan maka teknik analisa data yang digunakan adalah analisa kualitatif, dimana data yang diperoleh diklasifikasikan, ke dalam bentuk yang lebih mudah yaitu : ditabulasi, disortir sesuai dengan tujuan penelitian kemudian disajikan dalam bentuk tabel serta dideskripsikan dengan kata-kata untuk memperoleh kesimpulan.

\section{DESKRIPSI LOKASI PENETIAN}

\section{Kondisi Geografis}

Luas wilayah Kabupaten Biak Numfor sebesar $2.602 \mathrm{~km}^{2}$. Kabupaten Biak Numfor memiliki dua pulau besar, yaitu Pulau Biak dan Pulau Numfor serta sekitar 42 pulau-pulau kecil dengan 19 distrik. Letak Kabupaten Biak Numfor secara geografis terletak antara $134^{\circ} 47^{\prime}-136^{\circ}$ Bujur Timur dan $0^{\circ} 55^{\prime}-1^{\circ} 27^{\prime}$ Lintang Selatan. Batas - batas wilayah Kabupaten Biak Numfor, sebagai berikut:

a. Sebelah Utara berbatasan dengan Kabupaten Supiori dan Samudera Pasifik

b. Sebelah Selatan berbatasan dengan Selat Yapen

c. Sebelah Barat berbatasan dengan Kabupaten Manokwari d. Sebelah Timur berbatasan dengan Samudera Pasifik.

Iklim yang berlaku di wilayah Kabupaten Biak Numfor yaitu beriklim tropis basah dengan curah hujan yang tinggi. Berdasarkan hasil pencatatan Stasiun Meteorologi Kelas I Frans Kaisiepo Biak, suhu udara rata-rata di wilayah Kabupaten Biak Numfor selama tiga tahun terakhir tetap yaitu $27,1^{\circ} \mathrm{C}$. Suhu minimum ratarata pada tahun 2013 adalah $24,6^{\circ} \mathrm{C}$ sedangkan suhu maksimum rata-rata adalah $30,2^{\circ} \mathrm{C}$. Curah hujan di Kabupaten Biak Numfor tercatat rata-rata curah hujan adalah 241,3 mm per bulan. Dengan rata-rata jumlah hari hujan dalam satu bulan adalah 22 hari hujan, sehingga rata-rata curah hujan dalam satu hari adalah 10,97 $\mathrm{mm}$ per hari. Dalam setahun terakhir hujan deras terjadi pada bulan Juli (curah hujan 309,5 mm) dan Agustus (curah hujan 437,1 mm). Sebagian besar wilayah di Kabupaten Biak Numfor secara morfologi terbagi 4 (empat) yaitu daratan, datar berombak, berbukit dan bergunung Daerah dataran terletak terutama di daerah pantai dan sebagian merupakan hutan pantai, yaitu sekitar Pulau Biak, Bosnik, dan Marauw. Daerah yang bermorfologi berombak dengan kemiringan antara 3-15\% dimana luasnya lebih kurang 20\% dari Pulau Biak, serta terbentang dibagian tengah. Sebagian kecil berada di Kampung Wardo, Kota Biak dan ke arah timur serta sebagian Kampung Korem. Kondisi Tanah Kepulauan di wilayah Kabupaten Biak Numfor terbentuk dari batu karang metamorfik (filit, kuartit dan chrit) sebagai bagian dari lempengan Pasifik yang terdesak tanggul-tanggul Baltik. Jenis tanah yang terdapat di daerah ini adalah renzina litosol dan latosol yang terbentuk dari bahan induk batu gamping (dominan), batu karang dan bahan volanik. Pada daerah dengan relief datarberombak, jenis tanah didominasi oleh litosol dengan bahan induk batu karang. Jenis tanah ini memiliki tingkat kesuburan rendah, karena didominasi oleh tekstur pasir dengan solum tanah yang relatif dangkal.

\section{Keadaan Penduduk}

Penduduk merupakan salah satu indikator penting dari perkembangan dan pembangunan suatu wilayah, sehingga laju pertumbuhan penduduk perlu diperhatikan dengan biak. Laju pertumbuhan yang tinggi akan mencerminkan laju pertumbuhan angkatan kerja yang tinggi. Penduduk juga menjadi komponen yang penting 
bahkan menjadi pusat pertimbangan dalam setiap kegiatan pembangunan. Pada tahun 2013 Kabupaten Biak Numfor memiliki 19 Distrik yang terdiri dari 8 kelurahan dan 252 kampung/desa dengan jumlah penduduk berdasarkan data tahun 2013 adalah 135.080 jiwa yang terdiri dari 69.582 jiwa penduduk laki-laki dan 65.498 jiwa penduduk perempuan. Dengan luas wilayah 2.602 km2, kepadatan penduduk di Kabupaten Biak Numfor sebesar 51,91 jiwa per Km2 dapat dilihat pada Tabel 1.

Tabel 1. Jumlah Penduduk Menurut Luas Distrik, Rumah Tangga Dan Kepadatan Penduduk Tahun 2013

\begin{tabular}{|c|c|c|c|c|c|}
\hline No. & Distrik & $\begin{array}{l}\text { Luas } \\
\left(\mathbf{k m}^{2}\right)\end{array}$ & $\begin{array}{l}\text { Rumah } \\
\text { Tangga) }\end{array}$ & $\begin{array}{c}\text { Penduduk } \\
\text { (jiwa) }\end{array}$ & $\begin{array}{c}\text { Kepadatan } \\
\text { (jiwa/km) }\end{array}$ \\
\hline 1. & $\begin{array}{c}\text { Numfor } \\
\text { barat }\end{array}$ & 86,00 & 447 & 2.250 & 26,16 \\
\hline 2. & Orkeri & 51,62 & 339 & 1.887 & 36,56 \\
\hline 3. & $\begin{array}{c}\text { Numfor } \\
\text { Timur }\end{array}$ & 27,34 & 336 & 1.696 & 62,03 \\
\hline 4. & Poiru & 73,72 & 354 & 1.898 & 25,75 \\
\hline 5. & Bruyadori & 89,90 & 388 & 1.959 & 21,79 \\
\hline 6. & Padaido & 20,65 & 483 & 1.819 & 88,09 \\
\hline 7. & Aimando & 39,96 & 510 & 2.283 & 57,13 \\
\hline 8. & Oridek & 158,57 & 1.121 & 5.101 & 32,17 \\
\hline 9. & Biak Timur & 116,16 & 1.738 & 6.991 & 60,18 \\
\hline 10. & Biak Kota & 42,89 & 10.057 & 44.561 & $1.038,96$ \\
\hline 11. & Samofa & 204,25 & 6.762 & 29.630 & 145,07 \\
\hline 12. & Yendidori & 242,84 & 1.690 & 8.231 & 33,89 \\
\hline 13. & Biak Utara & 215,05 & 1.374 & 7.069 & 32,87 \\
\hline 14. & Andey & 119,14 & 495 & 2.569 & 21,56 \\
\hline 15. & W a r s a & 131,45 & 998 & 4.722 & 35,92 \\
\hline 16. & Yawosi & 108,44 & 414 & 2.101 & 19,37 \\
\hline 17. & Bondifuar & 108,42 & 44 & 221 & 2,04 \\
\hline 18. & Biak Barat & 220,38 & 988 & 5.701 & 25,87 \\
\hline \multirow[t]{2}{*}{19.} & Swandiwe & 213,06 & 700 & 4.228 & 19,84 \\
\hline & Jumlah & $2.269,84$ & 29.284 & 135.080 & 51,91 \\
\hline
\end{tabular}

Sumber : Badan Pusat Statistik Kabupaten Biak Numfor, 2013

Tabel 1 menunjukkan bahwa pepadatan tertinggi terjadi di Distrik Biak Kota, yakni hampir mencapai 1.034 jiwa per $\mathrm{Km} 2$, diikuti Distrik Samofa (hampir mendekati 128 jiwa per Km2) dan Distrik Warsa (hampir mendekati 70 jiwa per Km2). Sedangkan kepadatan terendah terdapat di Distrik Bondifuar, yakni mendekati 2 jiwa per Km2. Kepadatan penduduk tertinggi adalah di Distrik Biak Kota. Sedangkan Distrik dengan kepadatan penduduk terkecil adalah Distrik Bondifuar.

\section{Kondisi Perekonomian}

Perkembangan perekonomian suatu daerah dapat dilihat dari perkembangan pendapatan Domestik Regional Bruto (PDRB) Kabupaten Biak Numfor. Sub sektor yang paling dominan di Kabupaten Biak Numfor adalah sub sektor perkebunan tahunan dapat dilihat pada Tabel 2.
Tabel 2. Kontribusi PDRB Sup Sektor Pertanian Kabupaten Biak Numfor Tahun 2012-2016

\begin{tabular}{|c|c|c|c|c|c|c|}
\hline$\overline{\text { No }}$ & $\begin{array}{l}\text { Lapangan } \\
\text { Usaha }\end{array}$ & $\begin{array}{l}2012 \\
(\%)\end{array}$ & $\begin{array}{l}2013 \\
(\%)\end{array}$ & $\begin{array}{l}2014 \\
(\%)\end{array}$ & $\begin{array}{l}2015 \\
(\%)\end{array}$ & $\begin{array}{l}2016 \\
(\%)\end{array}$ \\
\hline 1. & $\begin{array}{l}\text { Tanaman } \\
\text { Pangan }\end{array}$ & 17,15 & 17,43 & 16,25 & 15,96 & 15,33 \\
\hline 2. & $\begin{array}{l}\text { Tanaman } \\
\text { Hortikultura } \\
\text { Semusim }\end{array}$ & 10.76 & 11,96 & 12,06 & 12,17 & 12,30 \\
\hline 3. & $\begin{array}{l}\text { Tanaman } \\
\text { Hortikultura } \\
\text { Tahunan dan } \\
\text { lainnya }\end{array}$ & 3.76 & 4.16 & 4,27 & 4,46 & 4,39 \\
\hline 4. & $\begin{array}{l}\text { Perkebunan } \\
\text { Tahunan }\end{array}$ & 42,63 & 39,33 & 39,88 & 39,85 & 40,06 \\
\hline 5. & Peternakan & 5,61 & 6,31 & 6,71 & 6,72 & 6,88 \\
\hline 6. & $\begin{array}{l}\text { Jasa } \\
\text { Pertanian dan } \\
\text { perburuan }\end{array}$ & 1,38 & 1,38 & 1,37 & 1,39 & 1,38 \\
\hline 7 & $\begin{array}{l}\text { Kehutanan } \\
\text { dan } \\
\text { Penebangan } \\
\text { Kayu }\end{array}$ & 2,36 & 2,36 & 2,26 & 2,19 & 2,04 \\
\hline 8. & Perikanan & 15,94 & 17,04 & 17,15 & 17,21 & 17,58 \\
\hline & PDRB & 100 & 100 & 100 & 100 & 100 \\
\hline
\end{tabular}

Tabel 2 menunjukkan bahwa sub sektor perkebunan tahunan memberikan kontribusi sebesar 40,06\% terhadap PDRB diikuti oleh sub sektor perikanan sebesar $17,85 \%$ dan sub sektor tanaman pangan sebagai sub sektor dominan ketiga di Kabupaten Biak Numfor sebesar 15,33\%. Pada Tabel 3 dibahas mengenai kontribusi sektor-sektor lain dalam perekonomian Kabupaten Biak Numfor, selain dalam sektor pertanian untuk melihat besarnya kontribusi terhadap pembentukan PDRB Kabupaten Biak Numfor. Sektor pertanian merupakan sektor dengan kontribusi terbesar dengan kontribusi terbesar yaitu $13,64 \%$ diikuti oleh sektor industri pengolahan dengan kontribusi sebesar $12,32 \%$.

Tabel 3. Kontribusi Sektor-sektor Perekonomian Terhadap PDRB Kabupaten Biak Numfor Tahun 2016

\begin{tabular}{|c|c|c|}
\hline No & Lapangan Usaha & 13,64 \\
\hline 1. & Pertanian & 7,31 \\
\hline 2. & Perdangan, hotel, restoran & 12.32 \\
\hline 3. & Industri pengolahan & 8,25 \\
\hline 4. & Listrik dan air bersih & 5,15 \\
\hline 5. & Transportasi dan pergudangan & 11,23 \\
\hline 6. & Perikanan laut. & 1,79 \\
\hline 7 & Angkutan komunikasi & 1,15 \\
\hline 8. & Bangunan & 7,90 \\
\hline 9. & Jasa pendidikan & 0,95 \\
\hline 10 . & Jasa keuangan dan asuransi & 13,64 \\
\hline 11. & Jasa kesehatan dan kegiatan social & 7,31 \\
\hline
\end{tabular}

\section{Profil Desa Dofyo Wafor}

Desa Dofyo Wafor merupakan salah satu Desa di Kecamatan Biak Utara. Desa Dofyo Wafor bedara pada ketinggian $60-120$ mdpl (meter diatas permukaan laut). dengan luas wilayah $10.000 .000 \mathrm{~m}^{2}$. Jumlah penduduk desa dofyo wafor terdiri dari Laki- 
laki 143 jiwa, perempuan 139 jiwa, jumlah 282 jiwa. Batas wilayah Desa Dofyo Wafor:
a. Sebelah Utara
: Desa Arwe
b. Sebelah Selatan
: Desa Douwnadik
c. Sebelah Timur
: Desa Warsansan
d. Sebelah barat
: Tanah adat Asyerem

\section{Mata Pencarian Pokok}

Data Penduduk menurut jenis pekerjaan yang ada di Desa Dofyo Wafor berdasarkan pada mata pencarian dapat dilihat pada Tabel 4.

Tabel 4. Jumlah Penduduk Berdasarkan Mata Pencarian

\begin{tabular}{clrr}
\multicolumn{4}{c}{ Desa Dofyo Wafor Tahun 2015 } \\
\hline No & \multicolumn{1}{c}{ Pekerjan } & Jumlah (orang) & Presentase (\%) \\
\hline 1. & Petani & 75 & 73,52 \\
2. & PNS/TNI/POLRI & 3 & 2,94 \\
3. & Karyawan swasta & 2 & 1,96 \\
4. & Pedagan & 4 & 3,92 \\
5. & Pensiunan & 3 & 2,94 \\
6. & Tukang bagunan & 2 & 1,96 \\
7. & Peternak & 3 & 2,94 \\
8. & Lain-lain/tidak & 10 & 9,80 \\
\multicolumn{4}{c}{ Jetap } \\
\hline
\end{tabular}

Sumber: Kantor Desa Dofyo Wafor, 2015

Berdasarkan Tabel 4 menunjukkan di Desa Dofyo Wafor jumlah penduduk yang mempunyai mata pencarian ada jumlah tersebut, kehidupannya bergantung di sektor pertanian ada 75 orang $73,52 \%$ dari total jumlah penduduk. Sebanyak 3 orang $/ 2,94 \%$ dari jumlah penduduk yang merupakan pensiunan PNS,TNI,POLRI dari total jumlah penduduk. Terbanyak ketiga adalah 3 orang peternak $12,94 \%$ dari jumlah penduduk yang mempunyai mata pencarian berbeda-beda ada yang berprofesi sebagai PNS,TNI, POLRI, pedagang, karyawan swasta, tukang bangunan, dan lain-lain.

\section{Kependudukan}

Berdasarkan Data admistrasi Pemerintah Desa, jumlah penduduk yang tercatat secara admistrasi, jumlah total 282 jiwa. Dengan rincian penduduk berjenis kelamin laki - laki berjumlah 143 jiwa, sendangkan berjenis kelamin perempuan berjumlah 139 jiwa. Data jumlah penduduk dapat dilihat pada Tabel 5.

Tabel 5. Jumlah Penduduk Berdasakan Jenis Kelamin Desa Dofyo Wafor Tahun 2015

\begin{tabular}{lccc}
\hline No. & Jenis Kelamin & Jumlah(orang) & Presentase (\%) \\
\hline 1. & Laki-laki & 143 & 50,8 \\
2. & Perempuan & 139 & 49,29 \\
\hline \multicolumn{4}{c}{ Sumber: Kantor Desa Dofyo Wafor, 2015 }
\end{tabular}

Tabel 5 menunjukkan bahwa informasi kedaaan kependudukan di Desa Dofyo Wafor dilakukan identifikasi jumlah penduduk dengan menitikberatkan pada klasifikasi usia dan jenis kelamin. Sehingga akan diperoleh gambaran tentang kependudukan Desa Dofyo Wafor yang lebih komprehentif. Untuk memperoleh informasi yang berkaitan dangan deskripsi tentang jumlah penduduk di Desa Dofyo Wafor berdasarkan usia dan jenis kelamin secara detail dapat dilihat dalam Tabel 6.

\begin{tabular}{lccccc}
\multicolumn{6}{c}{ Tabel 6. Jumlah Penduduk Berdasarkan Kelompok Usia Desa Dofyo } \\
Wafor Tahun 2015
\end{tabular}

Dari data tersebut diketahui bahwa jumlah perempuan usia produksi lebih dari jumlah laki-laki. Dengan demikian sebenarnya perempuan usia produktif di Desa Dofyo Wafor dapat menjadi tenaga produktif yang cukup signifikan untuk mengembangkan usaha-usaha produktif diharapkan semakin memperkuat ekonomi masyarakat, sementara ini masih bertumpu kepada tenaga produktif dari pihak laki-laki.

\section{Pendidikan}

Pendidikan adalah merupakan salah satu hal penting dalam memajukan tingkat kesejahteraan pada umumnya dan tingkat perekonomian dapa khususnya. Dengan tingkat pendidikan yang tinggi maka mendorong tingkat sumber daya manusia (SDM) itu sendiri. Tingkat ketrampilan juga akan meningkat tumbuhnya ketrampilan kewirausahaan. Dan pada gilirannya mendorong munculnya lapangan pekerjaan baru guna mengatasi pengangguran. Pendidikan biasanya akan dapat mempertajam sistimatika pikir atau pola pikir individu, selain itu mudah menerima informasi yang lebih maju. Tabel 7 menunjukkan tingkat rata-rata pendidikan Desa Dofyo Wafor. 
Tabel 7. Tingkat Pendidikan Rata-rata Desa Dofyo Wafor Tahun 2015

\begin{tabular}{ccc}
\hline No & Tinggkat pendidikan & Jumlah (orang) \\
\hline 1. & Tamat SD & 78 \\
2. & Tamat SLTP & 13 \\
3. & Tamat SMA/SMK & 10 \\
4. & Tamat D3 & 3 \\
5. & Tamat S1 & 2 \\
6. & Tidak sekolah & 20 \\
\hline & Jumlah & $\mathbf{1 2 4}$
\end{tabular}

Sumber: Kantor Desa Dofyo Wafor, 2015

\section{Agama Masyarakat Desa Dofyo Wafor}

Data penduduk menurut agama/aliran kepercayaan yang ada di Desa Dofyo Wafor berdasarkan jumlah keluarga dapat dijelaskan pada Tabel 8 .

Tabel 8. Jumlah Penduduk Berdasarkan Agama Desa Dofyo Wafor Tahun 2015

\begin{tabular}{lccc}
\hline No & Agama & $\begin{array}{c}\text { Jumlah } \\
(\text { KK) }\end{array}$ & Presentase (\%) \\
\hline 1. & Kristen & 60 & 80 \\
2. & Islam & 15 & 20 \\
\hline & Jumlah & $\mathbf{7 5}$ & $\mathbf{1 0 0}$
\end{tabular}

Sumber: Kantor Desa Dofyo Wafor, 2015

Tabel 8 menunjukkan bahwa jumlah penduduk Desa Dofyo Wafor yang beragama Kristen mendominasi dengan jumlah $60 \mathrm{KK}$ dari total jumlah penduduk / $80 \%$. pemeluk agama Islam $15 \mathrm{KK} / 20 \%$, Kristen Protestan dan Islam sebagai agama yang paling banyak dipeluk warga, mendominasi di seluruh penduduk yang ada di Desa Dofyo Wafor.

\section{Sarana dan Prasarana}

Data sarana dan prasarana yang digunakan oleh masyarakat di Desa Dofyo Wafor dapat dilihat pada Tabel 9.

Tabel 9. Sarana dan Prasarana Desa Dofyo Wafor Tahun 2015

\begin{tabular}{ccc}
\multicolumn{2}{c}{$\mathbf{2 0 1 5}$} & Unit \\
\hline No. & Sarana dan Prasarana & 1 \\
1. & SD & 1 \\
2. & Gereja & 1 \\
3. & Masjid & 1 \\
4. & Puskesmas & 1 \\
5. & Balai Desa & $\mathbf{5}$
\end{tabular}

Sumber: Kantor Desa Dofyo Wafor, 2015

\section{Potensi Desa Dofyo Wafor}

Potensi yang ada di Desa Dofyo Wafor yang dapat di manfaatkan oleh masyarakat petani untuk meningkatkan pendapatan, masyarakat petani Desa Dofyo Wafor untuk beberapa jenis tanaman pangan dan hortikultura dapat dilihat pada Tabel 10.
Tabel 10. Sub Sektor Pertanian Tanaman Pangan dan Hortikultura Desa Dofyo Wafor Tahun 2015

\begin{tabular}{lcc}
\hline Tanaman & $\begin{array}{c}\text { Luas Produksi } \\
\text { (Ha) }\end{array}$ & $\begin{array}{c}\text { Hasil Produksi } \\
\text { (Ton/Ha) }\end{array}$ \\
\hline Jagung & 5 & 15 \\
Umbi-umbian & 5 & 10 \\
Jahe & 10 & 20 \\
Tomat & 5 & 40 \\
Kubis & 4 & 15 \\
Daung bawang & 5 & 3 \\
Cabai & 2 & 40 \\
Kangkung & 2 & 5 \\
\hline Jumlah & $\mathbf{3 8}$ & $\mathbf{1 4 8}$ \\
\hline Sumber: Kantor Desa Dofyo Wafor, 2015
\end{tabular}

\section{HASIL DAN PEMBAHASAN}

\section{Kedudukan Tugas Pokok Dan Fungsi}

Tugas dan Fungsi Kelembagaan Dinas

Dalam Pemberdayaan Petani Hortikultura Sesuai Peraturan Daerah Kabupaten Biak Numfor Nomor 3 Tahun 2009. Menimbang bahwa dalam rangka implementasi penyelenggaraan otonomi daerah secara nyata dan bertanggungjawab, serta untuk meningkatkan dan mengoptimalkan pelayanan penyelenggaraan pemerintahan dan pembangunan guna meningkatkan kesejahteraan dan menciptakan kemakmuran secara menyeluruh kepada masyarakat Kabupaten Biak Numfor. maka tugas pokok Dinas Peternakan dan Pertanian Tanaman Pangan Kabupaten Biak Numfor yaitu :

1. Dinas Peternakan dan Pertanian Tanaman Pangan berkedudukan sebagai unsur pelaksana Pemerintah Daerah yang dipimpin oleh seorang Kepala yang berada di bawah dan bertanggungjawab kepada Bupati melalui Sekretaris Daerah.

2. Dinas Peternakan dan Pertanian Tanaman Pangan mempunyai tugas pokok melaksanakan kewenangan bidang Peternakan dan Pertanian Tanaman Pangan, serta tugas lainnya yang diberikan oleh Bupati.

3. Untuk menyelenggarakan tugas pokok sebagaimana dimaksud Dinas Peternakan dan Pertanian Tanaman Pangan mempunyai fungsi:

a. perumusan kebijakan teknis di bidang Peternakan dan Pertanian Tanaman Pangan. 
b. pemberian perizinan dan pelaksanaan pelayanan umum bidang Peternakan dan Pertanian Tanaman Pangan.

c. pembinaan terhadap Unit Pelaksana Teknis Dinas. dan

d. pelaksanaan Urusan Tata Usaha Dinas. Intansi Teknis yang menangani Pembangunan Pertanian Tanaman Pangan, Hortikultura dan Peternakan adalah Dinas Peternakan dan Pertanian Tanaman Pangan mempunyai Tugas Pokok dan Fungsi sebagai berikut: Tugas Pokok Merencanakan, merumuskan dan melaksanakan kebijaksanaan umum dibidang Peternakan dan Pertanian Tanaman Pangan adalah:

1. Menyusun Rencana Teknis Operasional Pembangunan Pertanian

2. Melaksanakan Kegiatan Pengembangan Pembangunan Pertanian

3. Mengkaji dan menganalisa Teknologi Pertanian

4. Melaksanakan Pelatihan, Pengujian dan Penerapan Teknologi

5. Melaksanakan Produksi Pertanian serta Pengembangan Peternakan serta Kesehatan Hewan dan Kesehatan Masyarakat Veteriner

6. Pembudidayaan Ternak serta Pembibitan

7. Melakukan koordinasi untuk pemuliaan dan sertifikasi bibit

8. Melaksanakan Tugas Pengawasan Operasional Kesehatan Ternak serta Peredaran obat-obatan untuk hewan

9. Pengawasan Ternak Pakan dan hasil ikutannya

10. Pemberdayaan Kelompok Tani / Ternak

11. Monitor dan Evaluasi serta menyampaikan pelaporan.

\section{Sumber Daya SKPD}

Jumlah Pegawai Negri Sipil (PNS) Dinas Peternakan dan Pertanian Tanaman Pangan Kabupaten Biak Numfor sampai dengan bulan januari 2017 berjumlah 29 orang. Dengan keadaan PNS secara akumulasi pengolongan ruang kepangkatan dapat dilihat pada Tabel 11.;

\begin{tabular}{|c|c|c|c|}
\hline Tabel & \multicolumn{3}{|c|}{$\begin{array}{l}\text { Kepangkatan pada Dinas Peternakan dan } \\
\text { Pertanian Kabupaten Biak Numfor }\end{array}$} \\
\hline No & Kepangkatan & $\begin{array}{l}\text { Jumlah } \\
\text { (orang) }\end{array}$ & Presentase (\%) \\
\hline 1. & Golongan IV & 4 & $11.43 \%$ \\
\hline 2. & Golongan III & 15 & $77.14 \%$ \\
\hline 3. & Golongan II & 10 & $11.43 \%$ \\
\hline & Jumlah & 29 & $100 \%$ \\
\hline
\end{tabular}

Jabatan struktural dan fungsional yang ada di Dinas Peternakan dan Pertanian Tanaman Pangan Kabupaten Biak Numfor setelah pemberlakuan Peraturan Daerah No. 3 Tahun 2013 adalah : satu (1) orang Kepala Dinas (Eselon IIb), satu (1) orang Sekretaris (Eselon IIIa), empat (3) orang Kepala bidang (Eselon IIIb) dan 15 orang Kepala Seksi/ Sub Bagian (Eselon IVa).

\section{Program Dan Kegiatan Pemberdayaan Petani}

Rencana Stretegis (RENSTRA) Dinas Pertanian baik di Kabupaten Biak Numfor maupun Provinsi Papua Tahun 2012-2016 ditetapkan tujuan pembangunan di bidang pertanian adalah :

1. Meningkatnya produksi dan produktivitas pertanian tanaman pangan, perkebunan,kehutanan, peternakan dan perikanan

2. Meningkatnya diversifikasi usaha tan.

3. Terwujudnya pengembangan teknologi pertanian

4. Meningkatnya peran kelembagaan dan pemberdayaan petani

5. Meningkatnya kualitas sarana dan prasarana pertanian dan

6. Meningkatnya kualitas SDM Pertanian.

Program dan kegiatan yang dilaksanakan oleh Dinas Peternakan dan Pertanian Tanaman Pangan Kabupaten Biak Numfor adalah berpacu dapa visi dan misi yaitu :" Mewujutkan Biak Numfor Bangkit, Mandiri, Sejahtera Untuk Perubahan". Sehinga berbagai program dan kegiatan dilaksanakan untuk mewujutkan pembagunan dalam bidang pertaian. Pengembangan secara umum telah dilakukan agar dapat mencapai sasaran. Seperti yang disampaikan oleh Kepala Dinas Peternakan dan Pertanian Tanaman Pangan Kabupaten Biak Numfor. Bpk. Imade. Suaryadana. “... program dan kegiatan yang telah kami laksanakan untuk 5 tahun kedepan di mana kami telah melaksanakan dan sudah memberikan hasil yang positif. Seperti perencanaan dan pengembangan Tanaman pangan dan hortikultura kami melakukan pemberdayaan dan merencanakan program-program bagi petani yang ada di Biak Numfor untuk meningkatkan usahatani, seperti yang ada di Desa Dofyo Wafor melalui pemberdayaan dan pembinaan kepada petani serta memberikan bantuan sarana. Untuk Perencanaan strategis tahun 2016-2020, akan 
lebih dioptimalkan upaya peningkatan produksi dan lebih khusus tanaman pangan dan hortikultura akan ada perlakuan-perlakuan tertentu untuk mengoptimalkan peningkatan produksi usahatani..." (wawancara, Selasa, 14/4/2017. Pukul 09. 15 ). Kemudian disampaikan juga oleh kepala bidang Tanaman Pangan dan hortikultura Bpk. Agustitus Tandilolo.“...perencanaan dan pengembangan usahatani hortikultura kami laksanakan melalui pemberdayaan dan penyuluhan langsung ke petani mengenahi tanaman pangan dan pengembangan usahatani hortikultura dan memberikan bantuan secara langsung, seperti menyediakan peningkatan sarana dan prasarana pertanian seperti traktor, alat pemberantas hama, pompa air dll...' (wawancara, selasa, 14/4/2017. Pukul 10.15).

\section{Program}

Sesuai pedoman perencanaan maka program yang akan dilaksanakan untuk periode 2016-2020 adalah sebagai berikut:

1. Program peningkatan produktifitas lahan kering

2. Program peningkatan ketahanan pangan

3. Program peningkatan kesejahteraan petani

4. Program peningkatan produksi pertanian tanaman pangan dan hortikultura

5. Program peningkatan penerapan teknologi pertanian dan peternakan

6. Program peningkatan produksi pertanian tanaman pangan dan hortikultura

7. Program fasilitasi alat pengolahan panen dan pascapanen

8. Program penerapan sistem pertanian organik

9. Program pengembangan kawasan komoditas unggulan

10. Program pengembangan pengolahan dan pemasaran produk pertanian

11. Program peningkatan pemasaran hasil produksi pertanian

12. Program pemberdayaan petani miskin

13. Program peningkatan sumber daya aparatur

14. Program pembangunan, rehabilitasi dan pemeliharaan infrastruktur

\section{Kegiatan}

Sesuai pedoman perencanaan maka kegiatan yang akan dilaksanakan untuk periode 2016-2020 adalah sebagai berikut:

1. Memberikan bantuan benih/bibit/komoditi pertanian tanaman pangan, hortikultura.

2. Penumbuhan dan pengembangan penangkar benih/bibit.
3. Pengawasan peredaran pupuk, pestisida.

4. Penyediaan sarana prasarana pembibitan pertanian.

5. Pembangunan embung/dam parit.

6. Pembangunan irigasi air permukaan.

7. Pembangunan jalan usaha tani (JUT).

8. Peningkatan penerapan bioteknologi pertanian dan peternakan.

9. Pengembangan sayuran organik.

10. Peningkatan mutu dan produksi hasil pertanian.

11. Peningkatan pemasaran hasil produksi pertanian.

12. Peningkatan kesejahteraan petani.

13. Fasilitasi permodalan usaha tani.

14. Pelatihan dan pendampingan kepada petani.

\section{Pemberdayaan Petani Hortikultura}

Bahwa sebagai bagian dari perencanaan pembangunan jangka menengah daerah (RPJMD) Kabupaten Biak Numfor, tujuan dan sasaran pembangunan pertanian Kabupaten Biak Numfor tahun 2016-2020 akan diwujudkan melalui pencapaian 4 (empat) target utama yaitu: (1) tercapainya swasembada pangan di Kabupaten Biak Numfor; (2) peningkatan produksi pertanian dan peternakan; (3) peningkatan nilai tambah dan daya saing komoditas pertanian; serta (4) peningkatan kesejahteraan petani. Selanjutnya target tersebut akan menjadi pedoman bagi Pemerintah Daerah dalam menetapkan sasaran pembangunan pertanian yang disesuaikan dengan potensi sumber daya serta karakteristik permasalahan yang dihadapi di lapangan. Disadari bahwa untuk mencapai target tersebut diatas tidaklah mudah, namun berdasarkan keragaan dan kinerja pembangunan pertanian selama 5 (lima) tahun terakhir dan dengan tekad kerja keras, kita optimis bahwa target tersebut dapat dicapai apabila para pemangku kepentingan dapat bekerja sama untuk mengatasi berbagai masalah dan kendala yang menjadi faktor penghambat utama serta memberikan dorongan yang diyakini akan menjadi faktor kunci pengungkit keberhasilan. Berbagai cara dilakukan oleh Dinas Peternakan dan Pertanian Tanaman Pangan Kabupaten Biak Numfor diakui oleh sebagian petani terutama di Desa Dofyo Wafor sebagai petani "Kami melihat beberapa program 
dari Dinas Pertanian, telah berupaya sehingga beberapa persoalan dalam pertanian khususnya Tanaman pangan dan hortikultura, dapat menjawabnya. Seperti sarana-prasarana pertanian. Meski demikian ada banyak persoalan-persoalan di bidang pertanian yaitu :

\section{Sarana Prasarana}

Prasarana dan sarana sangatlah penting untuk mendukung pertanian, agar berjalan dengan lancar harus ada prasarana dan sarana yang baik. Namun dari temuan dilapangan masih banyak sarana dan prasarana yang masih menghambat petani, terutama dalam prasarana dalam bertani, yaitu bibit unggul masih susah didapat, harga pupuk yang mahal, dan penggunaan alat pertanian yang masih tradisional.

\section{Pemberdayaan Kepada Petani}

Usaha dari pemerintah yang diwakili oleh Dinas Peternakan dan Pertanian Tanaman Pangan yaitu melalui pemberdayaan dalam bentuk : penyuluhan, pengawas penangkar benih, bantuan teknologi pertanian/ mesin pertanian, bantuan bibit unggul, pendampingan pengelolaan lahan, pembinaan kelembagaan dan petani. Namun hasil pemberdayaan yang dilakukan oleh pemerintah belum optimal. Dalam melakukan pemberdayaan pasti ada faktor pendorong dan penghambat bagi pemerintah, ini yang menjadi kelebihan dan kekurangan yang dihadapi pemerintah dalam menjalankan tugasnya dan bagi petani dalam menjalankan usahanya.

3. Faktor Pendorong Dalam Usahatani Hortikultura

Ada beberapa temuan yang menjadi pendorong dalam menjalankan usaha budidaya tanaman hortikultura yaitu: tanah yang sanga cocok untuk budidaya tanaman hortikultura seperti cabai, tomat, kubis, bawang daun, jahe dan berbagai jenis tanaman lainnya.

4. Faktor Penghambat Dalam Usahatani Hortikultura

Faktor penghambat ini yang menjadi kendala bagi petani dalam menjalankan usahanya. yaitu: tingkat kesuburan tanah menurun, bibit unggul masih susah didapat, banyak hama dan penyakit yang menyerang tanaman, belum adanya lembaga simpan pinjam khusus bagi petani, kurangnya penyuluhan.

\section{Luas Lahan Dan Jumlah Kelompok Tani}

Disamping itu adanya dukungan dari kelompok tani yang ada di Kabupaten Biak Numfor. yang berperan penting dalam menunjang usahatani untuk pencapaian sasaran produksi yang telah ditetapkan. Jumlah Kelompok Tani berdasarkan klasifikasi adalah sebagai berikut. Total Anggota kelompok Tani 8.971 dengan Luas Lahan Garapan 3.677 Ha. Total kelompok Tani sebanyak 580, yang terdiri dari kelompok Tani Desawa 499. Kelompok Tani Wanita, 78, kelompok Tani Pemuda 3 kelompok. Dapat dilihat pada lampiran 2. Selanjutnya, pertumbuhan yang membanggakan juga diperlihatkan oleh komoditas hortikultura selama 4 tahun terhakhir 2013-2016 walaupun peningkatannya setiap tahun berfluktuasi. Untuk lebih jelas data dilihat pada Tabel 12.

\begin{tabular}{cccc} 
Tabel 12. & $\begin{array}{c}\text { Perkembangan } \\
\text { Hortikultura Kabupaten Biak } \\
\text { Tahun 2013-2016. }\end{array}$ & $\begin{array}{c}\text { Komoditi } \\
\text { Numfor }\end{array}$ \\
\hline \multicolumn{4}{c}{ Produksi (Ton) } \\
\hline $\mathbf{2 0 1 3}$ & $\mathbf{2 0 1 3}$ & $\mathbf{2 0 1 5}$ & $\mathbf{2 0 1 6}$ \\
\hline & & & \\
5.753 & 7.201 & 6.739 & 6.727 \\
4.454 & 5.965 & 5.453 & 4.776 \\
1.459 & 2.674 & 3.224 & 3.324 \\
5.512 & 6.250 & 6.943 & 7.163 \\
6.074 & 7.037 & 10.384 & 9.767 \\
1.899 & 1.616 & 1.594 & 1.489 \\
4.979 & 4.704 & 4.093 & 4.193 \\
3.886 & 3.759 & 4.362 & 4.044 \\
4.571 & 5.498 & 4.237 & 4.053 \\
\hline
\end{tabular}

Sumber: Kantor Dinas pertanian. Kab. Biak Numfor, 2017

\section{Karakteristik Responden Masyarakat Petani}

Data responden kelopmok tani yang ada di Desa Dofyo Wafor berjumlah 3 kelompok tani dengan tingkat kelas pemula. Untuk lebih jelas dapat dilihat pada Tabel 13.

Tabel 13. Rekapitulasi Jumlah Kelompok Tani Di Desa Dofyo Wafor

\begin{tabular}{llccc}
\hline No. & $\begin{array}{l}\text { Nama } \\
\text { Kelompok }\end{array}$ & $\begin{array}{c}\text { Jumlah } \\
\text { Anggota }\end{array}$ & Responden & $\begin{array}{c}\text { Kelas } \\
\text { kelompok }\end{array}$ \\
\hline 1. & Lestari & 12 & 10 & Pemula \\
2. & Mekar Sari & 11 & 10 & Pemula \\
3. & Melati & 20 & 10 & Pemula \\
\hline & Jumlah & $\mathbf{4 2}$ & $\mathbf{3 0}$ & \\
\hline
\end{tabular}

Sumber: Desa Dofyo Wafor,2017 (diolah) 
Tabel 13 menunjukkan bahwa klasifikasi kelompok tani menunjukan bahwa tingkat kelas kelomok tani di Desa Dofyo Wafor masih pemula dalam kategori kelompok tani pemula ini disebabkan rendahnya tingkat teknis dan permasalahan yang ada belum tertangani secara maksimal. Hal ini menunjukkan bahwa kelas kelompok tani di lokasi penelitian kontak tani belum aktif, taraf pembentukan kelompok tani masih awal, pimpinan formal belum aktif, dan kegiatan kelompok bersifat informatif. Dari 3 kelompok tani yang ada didampingi oleh satu orang ketua kelompok. Kemudian respoden yang dipilih dari masing-masing kelompok berjumlah 30 responden.

\section{Identitas Dan Karateridtik Petani Responden}

Identitas dan karakteristik petani responden merupakan anggota yang dipilih di 3 kelompok tani yaitu: Kelompok tani Lestari, Kelompok tani Mekar Sari, Kelompok tani Melati. Jumlah responden dalam penelitian ini sebanyak 30 yang berhubungan dengan usatani dimana dalam menentukan responden dilakukan secara sengaja (purposive sampling) yaitu memili orang yang berkaitan dengan petani ketua dan anggota kelompok dalam melaksanakan pekerjaannya. Identifikasi ini meliputi : umur, pendidikan, luas lahan, status kepemilikan lahan, jumlah tanggunan keluarga, jenis usahatani yang diusahakan dan jenis bantutan yang diterima.

\section{Usia Responden}

Usia respoden dari petani yang di dapat dari hasil penelitian di Desa Dofyo Wafor dilihat pada Tabel 14 .

\begin{tabular}{ccc}
\multicolumn{3}{c}{ Tabel 14. Rekapitulasi Data Usia Respoden } \\
\hline Usia & Jumlah(orang) & Presentase (\%) \\
\hline$<30$ Tahun & 5 & $16 \%$ \\
30-50 Tahun & 19 & $64 \%$ \\
$>50$ & 6 & $20 \%$ \\
\hline Jumlah & $\mathbf{3 0}$ & $\mathbf{1 0 0}$ \\
\hline Sumber: Desa Dofyo & Wafor,2017 (diolah)
\end{tabular}

Tabel 14 menunjukkan bahwa rata-rata respoden berusia 30-50 tahun 64\%. Pada kategori usia tersebut respoden digolongkan pada usia produktif kerana kemampuan fisik untuk melakukan pekerjaan disektor pertanian masih tinggi.

\section{Pendidikan Responden}

Pendidikan respoden dari petani yang di dapat dari hasil penelitian di Desa Dofyo Wafor dilihat pada Tabel 15.

Tabel 15. Rekapitulasi Data Pendidikan Respoden

\begin{tabular}{ccc}
\hline Pendidikan & Jumlah (orang) & Presentase (\%) \\
\hline SD & 8 & 7 \\
SMP & 9 & 30 \\
SMA & 11 & 37 \\
Perguruan Tinggi & 2 & 6 \\
\hline Jumlah & $\mathbf{3 0}$ & $\mathbf{1 0 0}$ \\
\hline Sumber: Desa Dofyo Wafor,2017 (diolah)
\end{tabular}

Tabel 15 menunjukkan bahwa pendidikan formalnya, dengan tingkat pendidikan SD berjumlah 8 responden dengan persentase $7 \%$, tingkat pendidikan SMP berjumlah 9 responden dengan presentase $30 \%$, tingkat pedidikan SMA berjumlah 11 responden dengan presentase $37 \%$, dan tingkat pendidikan di Perguruan Tinggi berjumlah 2 responden. Ini menunjukan bahwa tingkat pedidikan responden yang paling banyak ada di tingkat SMA dengan jumlah 11 responden.

\section{Luas Lahan Responden}

Luas lahan responden dapat dilihat pada Tabel 16.

Tabel 16. Rekapitulasi Data Responden Berdasarkan Luas lahan

\begin{tabular}{ccc}
\multicolumn{2}{c}{ Luas lahan } & \\
\hline Luas Lahan & $\begin{array}{c}\text { Jumlah } \\
\text { (orang) }\end{array}$ & $\begin{array}{c}\text { Persentase } \\
(\boldsymbol{\%})\end{array}$ \\
\hline $0,10-0,30 \mathrm{Ha}$ & 1 & 3 \\
$0,31-0,50 \mathrm{Ha}$ & 20 & 67 \\
$0,51-1 \mathrm{Ha}$ & 9 & 30 \\
\hline Jumlah & $\mathbf{3 0}$ & $\mathbf{1 0 0}$
\end{tabular}

Sumber: Desa Dofyo Wafor,2017 (diolah)

Tabel 16 menunjukkan bahwa luas lahan yang dimiliki oleh petani responden ratarata petani memiliki luas lahan sebesar 0,100,30 Ha sebanyak 1 responden dengan persentase $3 \%$, sendangkan petani yang memiliki luas lahan 0,31-0,50 Ha sebanyak 20 responden dengan persentase $67 \%$, dan untuk luas lahan 0,51- $1 \mathrm{Ha}$ memiliki luas lahan sebanyak 9 responden dengan persentase $30 \%$.

\section{Status Lahan Yang Digunakan}

Status laha yang digunakan oleh respoden yang di dapat dari hasil penelitian di Desa Dofyo Wafor dilihat pada Tabel 17. 
Tabel 17. Rekapitulasi Data Responden Berdasarkan Status Lahan Yang Digunakan

\begin{tabular}{ccc}
\hline $\begin{array}{c}\text { Status Kepemlikan } \\
\text { Lahan }\end{array}$ & $\begin{array}{c}\text { Jumlah } \\
\text { (orang) }\end{array}$ & $\begin{array}{c}\text { Persentase } \\
(\mathbf{\%})\end{array}$ \\
\hline Milik Sendiri & 10 & 30 \\
Sewa/Pinjaman & 20 & 70 \\
\hline Jumlah & $\mathbf{3 0}$ & $\mathbf{1 0 0}$
\end{tabular}

Sumber: Desa Dofyo Wafor,2017 (diolah)

Tabel 17 menunjukkan bahwa status lahan yang digunakan berdasarkan milik sendiri dengan jumlah 10 responden dengan persentase $30 \%$, pada status lahan yang digunakan melalui sewa/pinjaman dengan jumlah 20 responden dengan persentase $70 \%$.

\section{Tanggunan Keluarga}

Jumlah tanggunan keluarga juga akan mempengaruhi pada tingkat kesejahteraan keluarga terutama pada keluarga yang mempunyai tingkat pendapatan rendah. Dapat dilihat pada Tabel 18.

Tabel 18. Rekapitulasi Data Respoden Berdasarkan

\begin{tabular}{ccc}
\multicolumn{2}{c}{ Tanggungan Keluarga } \\
\hline $\begin{array}{c}\text { Jumlah Anggota } \\
\text { Keluarga }\end{array}$ & $\begin{array}{c}\text { Jumlah } \\
\text { (orang) }\end{array}$ & $\begin{array}{c}\text { Persentase } \\
(\boldsymbol{\%})\end{array}$ \\
\hline $1-3$ & 5 & 17 \\
$4-6$ & 10 & 33 \\
Lebih dari 6 & 15 & 50 \\
\hline Jumlah & $\mathbf{3 0}$ & $\mathbf{1 0 0}$ \\
\hline Sumber: Desa Dofyo Wafor, 2017 (diolah)
\end{tabular}

Tabel 18 menunjukkan bahwa rata-rata jumlah tanggungan keluarga responden 1-3 berjumlah 5 orang dengan persentase $17 \%$, sendangkan sebanyak 4-6 orang berjumlah 10 orang dengan persentase 33\%, lebih dari 6 berjumlah 15 orang dengan persentase $50 \%$.

\section{Jenis Usahatani Yang Diusahakan}

Beberapa jenis tanaman hortikultura yang diusahakan oleh respoden yaitu, cabai, tomat dan kubis dapat dilihat pada Tabel 19.

Tabel 19. Rekapitulasi Data Respoden Berdasarkan Jenis Tanaman

\begin{tabular}{ccc}
\hline Jenis Tanaman & $\begin{array}{c}\text { Jumlah } \\
\text { (orang) }\end{array}$ & $\begin{array}{c}\text { Presentase } \\
(\mathbf{\%})\end{array}$ \\
\hline Cabai & 10 & 50 \\
Tomat & 5 & 25 \\
Kubis & 5 & 25 \\
\hline Total & $\mathbf{3 0}$ & $\mathbf{1 0 0}$ \\
\hline \multicolumn{2}{l}{ Sumber: Desa Dofyo Wafor,2017 (diolah) }
\end{tabular}

Tabel 19 menunjukkan bahwa mayoritas responden menanam tanaman cabai dengan jumlah 10 respoden dengan presentase $50 \%$. Dan untuk tanaman tomat berjumlah 5 respoden dengan presentase $25 \%$, diikuti tanaman kubis 5 respoden dengan presentase $25 \%$. Cabai keriting merupakan salah satu komuditas sayuran yang banyak dibudidayakan oleh petani, di Desa Desa Dofyo Wafor karena memiliki harga jual yang tinggi cabai keriting. Tanaman kubis hingga saat ini merupakan tanaman yang sedang dibudidayakan oleh petani di Desa Dofyo Wafor. Tanaman ungulan di Desa Dofyo Wafor adalah pengembangan tanaman jahe yang sangat subur serta memiliki kualitas sangat baik, dan sudah di pasarkan ke beberapa daerah di Papua. tetapi sampai saat ini belum ada pengembangan dalam skalah produksi, sehingga petani menjual langsung ke pasar dengan harga murah.

\section{Jenis Bantuan Yang Diterima}

Bantuan dan fasilitas yang diberikan oleh pemerintah untuk menunjang usahatani tanaman pangan dan hortikultura di Desa Wafor, seperti penyediaan sarana dan prasarana pengairan, yaitu. Tambak pengairan, profil penampungan air, alat semprot

\section{Hasil Wawancara}

Hasil wawancara yang dilakukan pada 2 orang informan yang berasal dari unsur pemerintah dan anggota kelompok tani yang ada di Desa Dofyo Wafor secara garis besar menunjukkan beberapa hal, yaitu:

1. Program pelatihan yang berhubungan dengan kegiatan peningkatan pengembangan usaha telah dilakukan oleh pemerintah melalui kegiatan pemberdayaan masyarakat petani.

2. Pemerintah selalu berusaha memotivasi masyarakat dengan memanfaatkan melalui kegiatan sosial. Memfungsikan perangkat Desa dalam memonitoring perkembangan usahatani.

3. Pemerintah telah menfasilitasi petani dengan memberikan bantuan sarana irigasi pengairan, modal,bibit, pupuk, dan alat-alat pertanian lainnya.

4. Kegiatan pengembangan usahatani tanaman pangan dan hortikultura dilaksanakan 
melalui program-program yang telah ditetapkan dalam Rencana Strategis (RESNTRA) yaitu: meningkatkan produksi dan produktivitas petanian dan tanaman pangan, meningkatkan diversifikasi usatani, pengembangan tenologi pertanian, meningkatkan peran kelembagaan pemberdayaan petani, meningkatkan kualitas sarana dan prasarana pertanian,menigkatkan kualitas SDM petanian.

5. Program pemberdayaan petani hortikultura juga sudah memberikan hasil yang sangat baik dimana petani sudah memenuhi kebutuhan masyarakat di pasar, akan komuditi hortikultura dan juga dikirim ke beberapa daerah di papua dan meraka sudah mendapaktan keuntungan untuk memenuhi kebutuhan sehari-hari.

6. Pengembangan tanaman hortikultura di Kabupaten Biak Numfor pemerintah telah melaksanakan pembangunan infrastruktur terutama jalan untuk memudakan petani menjualkan hasil pertanian ke pasar.

Sementara itu, beberapa petani juga memberikan penjelasan mengenahi peranan pemerintah dalam usahatani hortikultura. Pemerintah telah bekerja sama dengan petani dan memberikan fasilitas untuk menunjang usahatani sesuai permintaan masyarakat petani yaitu: sarana irigasi pengairan, alat penyemprot hama, bibit, pupuk, modal, dan peralatan pertanian lainnya. Pemerintah telah melakukan sosialisasi dan pelatihan kepada kami melalui kegiatan-kegiatan serta penyuluhan yang dilaksanakan ditingkat kecamatan dan desa. Upaya untuk meningkatkan pendapatan masyarakat petani melalui program dan pelatihan yang dilakukan oleh pemerintah antara lain, yaitu:

1. Pengembangan motivasi bekerja dan berusaha pelatihan.

2. Program peningkatan produktifitas lahan kering.

3. Program peningkatan produksi pertanian tanaman pangan dan hortikultura.

4. Program peningkatan penerapan teknologi pertanian.

5. Pelatihan keterampilan usaha ekonomi.

6. Pelatihan pengembangan usahatani tanaman pangan dan hortikultura.

\section{KESIMPULAN DAN SARAN}

\section{Kesimpulan}

Berdasarkan penelitian yang dilakukan maka diperoleh kesimpulan bahwa Pemerintah dalam pemberdayaan usahatani hortikultura di Kabupaten Biak Numfor. Khususnya di Desa Dofyo Wafor, melalui Dinas Peternakan dan Pertanian Tanaman Pangan Kabupaten Biak Numfor telah melakukan pemberdayaan kepada petani, pemberdayaan yang dilakukan dalam bentuk penyuluhan, pengawas penangkar benih, pemberikan bantuan bibit unggul, sarana irigasi pengairan, pendorong kemajuan teknologi, pendampingan dalam pengelolaan lahan, dan pendampingan dalam kelembagaan petani. Namun pemberdayaan yang diberikan oleh pemerintah belum berhasil, karena jika dilihat dari keadaan petani yang ada dilapangan saat ini, petani masih mengalami ketergantungan terhadap bantuan dari pemerintah, dan juga petani hortikultura belum mampu menaikan kembali produktifitasnya hingga mengekspor hasil pertaniannya. Sehingga tujuan dari pemberdayaan untuk membuat petani mandiri, dan berdaya saing belum dapat tercapai. Tujuan dari pemberdayaan kepada petani agar terciptanya masyarakat yang berdaya saing dan mandiri. Peluang yang ada saat ini di Desa Dofyo Wafor yaitu sudah adanya sarana dan prasarana sebagai penunjang dari usaha dibidang pertanian, sedangkan hambatan yang ada yaitu adanya serangan hama dan penyakit pada tanaman pertanian, terbatasnya pengetahuan, ketrampilan dan permodalan petani, dan juga posisi tawar produk pertanian yang masih rendah. Dengan melihat peluang dan hambatan, maka Dinas Peternakan dan Pertanian Tanaman Pangan dalam membina masyrakat petani di Desa Dofyo Wafor diharapkan agar terus ditingkatkan untuk mengurangi hambatan yang ada, sehingga kesejahteraan dan taraf hidup masyarakat petani dapat meningkat.

\section{Saran}

Beberapa masukan yang diperoleh dari hasil penelitian dapat dijadikan bahan acauan baik bagi Pemerintah Kabupaten Biak Numfor, Dinas Peternakan dan Pertanian Tanaman Pangan Kabupaten Biak Numfor, Badan Penyuluh Pertanian, maupun bagi petani untuk bersama- 
sama dapat bekerja sama guna mengembangkan usahatani tanaman pangan dan hortikultura.

\section{DAFTAR PUSTAKA}

Ainda, 2013. " Prospek Agribisnis Hortikultura 5 Tahun di Indonesia.' 'http:// aindapryl.blogspot.com/2013/04/ prospek tahun.html. Diakses pada 10 September 2016.

Andrew, 2005. Konsep Strategi Perusahaan, Penerbit Erlangga, Jakarta.

Astrid S. Susanto, Pengantar Sosiologi dan Perubahan Sosial, Bina Cita, 1983. Hal. 95.

Badan Pusat Statistik (BPS) Kabupaten Biak Numfor, Kabupaten Biak Numfor Dalam Angka, Tahun 2003.

Balitbanghort (Balai Penelitian Hortikultura) Departemen Pertanian, 2008. Sistem Usahatani Sayuran Berwawasan Konservasi. Pusat Penelitian dan Pengembangan. Hortikultura.pushor@ rad.net.id, Diakses pada 12 September 2016.

Direktorat Jenderal Bina Produksi Hortikultura 2002. Profil Komoditi Kubis. Direktorat Tanaman Sayuran Hias dan Aneka Tanaman. Jakarta

Fadhli Nurdin . Pengantar Studi Kesejahteraan sosial, Jakarta Gramedia 2004

Final P. 2006. Mengatasi Permasalahan Bertanam Cabai. Penebar Swadaya. Jakarta.Hal 220.

Hikmat, 2004. Strategi Pemberdayaan Masyarakat: Humaniora Utama. Bandung

Inu Kencana Syafiie, Ilmu Pemerintahan, CU Mandar Maju, Bandung, 1994, hal 229.
Koentjaraningrat, Metode-metode Penelitian Masyarakat, Jakarta Gramedia, 1993. Hal 21.

Koentjaraningrat, Pengantar Ilmu Antropologi, Bumi Aksara, Jakarta, 1989. Hal 169.

Masri Singarimbun Dan Efendi. Metode Penelitian Survei, Jakarta, 1997. Hal. 23.

Mirsadiq,2012."'Hortikultura”'http://mirsadid.w ordpress.com/2012/01/08/hotikultu ra2/html. Diakses pada senin 12 September 2016

Moleong, L. J. 2003. Metodologi Kualitatif.: PT. Remaja Rosadakarya Bandung.

Narwoko, Dwi J dan BagongSuyanto. 2004. Sosiologi Teks Pengantar dan Terapan. Jakarta: Prenada Media.

Nasrul, 2012. Pengembangan Kelembagaan Pertanian Untuk Kapasitas Petani terhadap Pembangunan Pertanian. Vol. 3, (No 29): 166-174.

Natsir, 2003. Metode Penelitian, Jakarta, 1999. Hal 405

Peter Salim dan Yeny Salim, 2004. Kamus Bahasa Indonesia Kontemporer, Modern English Press, Jakarta, 1991. Hal 1132.

Pracaya. 2005. Kol Aliyas Kubis. Penebar Swadaya. Jakarta.

Press, 2012. Hortikultura. http://mirsadiq Wordpress.com/2012/01/08/hortikul tura-2/. Diakses pada 12 September 2016.

Riswandha Imawan, Dampak Pembangunan Nasional Terhadap Peningkatan Kemajuan Daerah, laporan penelitian Pusat Antar Universitas (PAU), Studi Sosial, UGM, Yogyakarta, 1991, hal 12. 
Renstra Dinas Pertanian Tanaman Pangan dan Hortikultura Kabupaten Biak Numfor. Tahun 2012 s/d 2016.

Rukmana, R.,2004. Kacang Hijau: Budidaya dan pasca panen. Kanius, Yogyakarta.

Saskia, 2012. Biaya dan Pendapatan Usahatani Tebu Menurut Status Kontrak (Studi Kasus di PT IGN Cepiring, Kab Kendal). Semarang Fakultas Ekonomika dan Bisnis Universitas Diponegoro.

Soerjono Soekamto, 1987 Sosiologi Suatu Penngantar, Rajawali Pres, Jakarta

Soetomo. 2013. Pemberdayaan Masyarakat, Mngkinkah Muncul Antitesisnya? (Cetakan Kedua). Pustaka Belajar. Yogyakarta.

Sunu, Pratignjadan Wartoyo. 2006. Buku Ajar Dasar Hortikultur http://pertanian.uns ac.id/ agronomi/dashor. html. Diakses pada 12 September 2016.
Suparjan \& Hempri Suyatno, Pengembangan Masyarakat Pembangunan Sampai Pemberdayaan, Aditya Media, Yogyakarta, 2003 hal 44.

The Liang Gie, Pertumbuhan Pemerintah Daerah di Negara Republik Indonesia, Rajawali Press- Jakarta 1986, hal 44

Undang-Undang No. 32 Tahun 2004 Tentang Pemerintah Daerah.

Yustika, Ahmad Erani, 2010. Ekonomi Kelembagaan: Definisi, Teori, Strategi 2nd ed.: Penerbit Bayumedia. Malang

Zubaedi. 2013. Pengembangan Masyarakat, Wacana dan Praktik: Kencana Prenada Media Group, Jakarta.

Zulkarnain, 2010. Dasar-Dasar Hortikultura: Bumi Aksara, Jakarta 